\title{
Implementation of Tegal City Government Policy on Small Business Loans in Empowering Small and Medium Enterprises
}

\author{
Taufiqurokhman Taufiqurokhman ${ }^{1}$, Andriansyah Andriansyah ${ }^{2}$, Hastin Trustisari $^{3}$ \\ \{taufiqurokhman@dsn.moestopo.ac.id ${ }^{1}$, andriansyah@dsn.moestopo.ac.id ${ }^{2}$, hustin@ binawan.ac.id $^{3}$ \} \\ ${ }^{1,2}$ Faculty of Social and Political Sciences, Universitas Prof. Dr. Moesopo (Beragama), Jalan Hanglekir \\ I Number 8 Jakarta, Indonesia \\ ${ }^{3}$ Social Welfare Study Programe, Faculty of Social and Political Sciences, Universitas Binawan, Jalan \\ Raya Kalibata Nomor 25 East Jakarta Indonesia
}

\begin{abstract}
The aim of the study was to see the extent to which the Government's policy implementation on People's Business Credit empowering Warung Tegal's small-scale business in Margadana Sub-District, Tegal City could lift the economy and the welfare of the community. Research methodology uses quantitative methods, using statistics by taking samples and informants who have been determined before. While diseaint research using George Edward III's toeri. Research location in Margadana district. The Quantitative Method referred to is based on the philosophy of positivism, used to examine certain populations or samples. Data analysis is quantitative or statistical, with the aim of testing the predetermined hypothesis. The results of the study: the implementation of Government policies on People's Business Credit Empowering Warung Tegal Small and Medium Enterprises in Margadana Sub-District was 45.29 percent. The remaining 54.71 percent are other factors. Other factors: cause not optimal because small businesses have not been incorporated, the location of residence and business is different, which causes illegal levies.
\end{abstract}

Keywords: Policy Implementation, Tegal City Government, Empowering Small and Medium Enterprises.

\section{Introduction}

The Warung Tegal business is usually abbreviated as Warteg, is one type of business that can be classified as a Micro Business, as well as a Small Business which is classified as the Micro, Small and Medium Business [1] and included to informal sector [2]. In accordance with Law Number 20 of 2008, concerning Micro, Small and Medium Enterprises (MSMEs). then the limitations of Micro and Small Businesses are defined as follows: (a) Microbusinesses are productive businesses owned by individuals and or business entities that meet the criteria of Micro Businesses as stipulated in this Law; (b) Small-scale business is a productive economic enterprise that is independent, carried out by individuals or business entities that are not subsidiaries or branches of companies that are owned, controlled or become part of either direct or indirect business of medium-sized businesses or large businesses that meets the criteria of Small Business [3].

In order to realize community empowerment, on November 5, 2007, the Government of Indonesia launched a People's Business Credit Program to assist the capital of the Small 
and Medium Enterprises sector [2]. The People's Business Credit, hereinafter referred to as KUR, is working capital credit and / or investment credit provided by Banking to Micro, Small and Medium Enterprises and cooperatives, which are feasible [4]. That is, the business has good business prospects and has the ability to return but has not been bankable or has not been able to meet the credit or financing requirements of the executing Bank, among others in providing collateral and fulfilling credit or financing requirements in accordance with the provisions of the Executing Bank including the Small Business sector And Middle [5]. Having a productive business that is supported by a guarantee program. The operational foundation of the People's Business Credit is Presidential Regulation number 2 of 2008, concerning the Guarantee Institution, which regulates guarantee institutions both financial institutions in the form of Banks. And non-bank financial institutions that will provide credit guarantees [6]. In this case the researcher focuses on research on People's Business Credit in Tegal City in empowering the community [7]. That is about the Implementation of the People's Business Credit Policy in Empowering Small Businesses and Enforcing Warung Tegal in the Government of Tegal City. In this case, the people of Tegal City open a lot of small and medium enterprises to Warung Tegal. One of the biggest livelihoods of the people of Tegal City, namely as many as 18.59 percent are traders and 10 percent, among them are Traders of Warung Tegal. Besides that, Warung Tegal is also an icon or characteristic of Tegal City, especially in Margadana District, which is expected to improve the economy [8]. Furthermore, the author will explain the analysis of the Implementation of Tegal City Government Policy on Small Business Loans in Empowering Small and Medium Enterprises by taking research locations in the Tegal City Government towards Small and Medium Enterprises conducted by the Tegal City Trade, Industry and Cooperative Office, especially in Kecamatan District Margadana.

\section{Research Method}

The study was conducted using a quantitative approach that can be interpreted as "this research method is based on the philosophy of positivism, used to examine certain populations or samples, collecting data using research instruments, analyzing quantitative or statistical data, with the purpose of testing the predetermined hypothesis [9]. Location and Time Research: the study took place in Margadana District, Tegal City as a research area. This location was taken because the economy in this region grew at a fairly high economic rate, one of which was the emergence of the Small and Medium Enterprises namely Wrung Tegal as a support for the welfare of the kelauarga which also supported the economy of the people of Tegal City. The implementation of the Tegal City Government policy has greatly developed the People's Business credit program for the empowerment of small and medium enterprises in the margadana sub-district of Tegal City that can improve people's welfare. Therefore, with the People's Business Credit program the empowerment of legal stall entrepreneurs in the margadana sub-district of Tegal City must be further improved given that the Warteg UKM actually has considerable potential to develop. From the description above, with quantitative research methodology, the approach of the researcher argues as follows: (a) Policy is a series of specific actions and carried out in a certain time sequence based on the implementation of Government policy on People's Business Credit to the effectiveness of Warteg SME empowerment in Margadana District, Tegal City; (b) Implementation of Government policies based on factors that influence the implementation of policies, namely: Communication, Resources, Attitudes of implementing policies and bureaucratic structures; 
(c) Empowerment is a measure that states how far the target (strength, quality, and time) is achieved, so that the greater the target achieved, the higher the success.

The object of the research is the target to get a data. In accordance with the opinion of Sugiyono (2008) defines the object of research are as follows: The object of research is the scientific goal to obtain data with a specific purpose and usefulness about something objective, valid and reliable about something (certain variables) [9]. "Definition of research objects according to I Made Wirartha (2006) states that: Research Objects (research variables) are certain characteristics that have different values, scores or sizes for different units or individuals or are concepts that are given more than one value. The object of research is a scientific goal with a specific purpose and purpose to obtain certain data that has a different value, score or size. The object of research is a goal with the purpose and usefulness of obtaining certain data. The object of research in this paper is the Influence of Government Policy Implementation (Tegal City Government, Margadana District), about People's Business Credit (variable $\mathrm{X}$ ) in Empowering Warung Tegal Small and Medium Enterprises (Y variable).

\section{Result and Discussion}

\section{a. Overview of the State of the Research Object.}

Administratively, Margadana District is included in the Tegal City area which is part of the Central Java Province of Indonesia. Which is located on the north coast of the island of Java. Margadana Subdistrict includes seven Sub-Districts and consists of 34 Community Houses and 189 Neighborhood Groups, following are the names and area of the kelurahan within the Margadana District area.

Table 1. Community Livelihoods in Tegal City

\begin{tabular}{|c|c|c|}
\hline No & Livelihood Types & Amount (people) \\
\hline 1 & Own Farmer & 1.692 \\
\hline 2 & Farm workers & 5.209 \\
\hline 3 & Fisherman & 141 \\
\hline 4 & Entrepreneur & 267 \\
\hline 5 & Industrial Workers & 5.451 \\
\hline 6 & Bagunan Workers & 2.374 \\
\hline 7 & Warung Tegal Traders / Traders & 11.479 \\
\hline 8 & Transportation & 1.308 \\
\hline 9 & $\begin{array}{l}\text { Civil Servants / Indonesian National Army / } \\
\text { Indonesian Police }\end{array}$ & 457 \\
\hline 10 & Retired & 222 \\
\hline 11 & Etc & 9.263 \\
\hline \multicolumn{2}{|r|}{ Total } & 37.863 \\
\hline
\end{tabular}

Source: Tegal City Industry and Cooperative Office, 2018.

Demographically, the condition of the population of the margadana sub-districts spread across seven villages is densely populated, but there are relatively quite dense ones, in general the distribution of the population with the composition is as follows:

Table 2. Number of Entrepreneurs in Warung Tegal in Margadana District

\begin{tabular}{ccc}
\hline No & Name & Total \\
Kelurahan & Warung Tegal Entrepreneurs \\
\hline
\end{tabular}




\begin{tabular}{llc}
\hline 1 & Kaligangsa & 26 \\
2 & Krandon & 83 \\
3 & Cabawan & 58 \\
4 & Kalinyamat Kulon & 97 \\
5 & Margadana & 33 \\
6 & Sumurpanggang & 97 \\
7 & Pesurungan Lor & 46 \\
\hline & Total & 440 \\
\hline
\end{tabular}

Source: Margadana District, Tegal City, 2018

The average population density in the Margadana sub-district of Tegal City in 2011 was 4,479 people $/ \mathrm{km}^{2}$ with the highest population density in the Sumurpanggang sub-district of 641 people $/ \mathrm{km}^{2}$ and the lowest density in the Pesurungan Lor village was 253 people $/ \mathrm{Km}^{2}$. While the livelihoods of the residents of Margandana Subdistrict, Tegal City, Central Java Province mostly depend on Warung Tegal Small and Medium Enterprises as many as 11,479 people. As shown in Table D.3 Livelihood of Margandana District, Tegal City below:

Table 3. Number of Entrepreneurs in Warung Tegal in Margadana District

\begin{tabular}{llc}
\hline No & \multicolumn{1}{c}{$\begin{array}{c}\text { Name of } \\
\text { Kelurahan }\end{array}$} & $\begin{array}{c}\text { Total } \\
\text { Warung Tegal Entrepreneurs }\end{array}$ \\
\hline 1 & Kaligangsa & 26 \\
2 & Krandon & 83 \\
3 & Cabawan & 58 \\
4 & Kalinyamat Kulon & 97 \\
5 & Margadana & 33 \\
6 & Sumurpanggang & 97 \\
7 & Pesurungan Lor & 46 \\
\hline \multicolumn{2}{r}{ Total }
\end{tabular}

Source: Margadana District, Tegal City, 2018

In detail, the number of Small and Medium Enterprises in Margandana Subdistrict is explained in the Table below:

Tabel 4. Number of Warteg Entrepreneur in Margadana District

\begin{tabular}{clc}
\hline No & \multicolumn{1}{c}{ Nema of Kelurahan } & Number of Warteg Entrepreneur \\
\hline 1 & Kaligangsa & 26 \\
2 & Krandon & 83 \\
3 & Cabawan & 58 \\
4 & Kalinyamat Kulon & 97 \\
5 & Margadana & 33 \\
6 & Sumurpanggang & 97 \\
7 & Pesurungan Lor & 46 \\
\hline & $\quad$ Total & 440 \\
\hline
\end{tabular}

Source: Margadana District, Tegal City, 2017 


\section{b. Implementation of Public Policy, People's Business Credit and Community Empowerment \\ i. Implementation of Public Policy}

The implementation of the Tegal City government policy on people's business credit in empowering Warung Tegal Small and Medium Enterprises in the Margadana District of Tegal City is applied as follows: success or failure in achieving the objectives requires further action, namely the implementation of policies. In this study the author takes a theoretical approach according to George Edward III, (2002) arguing that in the implementation of the policy implementation variables are needed, namely the factors that implement the policy, are: (a) Communication plays an important role in the policy process, namely transmission, consistency and clarity (clarity). The first requirement for effective policy implementation is that those who make decisions must know what they must do. Policy decisions and orders must be forwarded to personnel right before the decisions and orders can be followed. Communication must be accurate and must be carefully understood by the implementers. Implementation orders may be continued carefully, clearly and consistently, but if the implementers lack the resources needed to implement policies, even this implementation tends to be ineffective; (b) Resources can be important factors to include adequate staff and good skills to carry out their duties, authority and facilities needed to translate proposals on paper to carry out public services ; (c) The trends of policy implementers are the third factor that has important consequences for effective policy implementation. If the implementers are kind to a particular policy, and this is support, chances are they are implementing policies as desired by the initial decision makers; (d) The structure of the bureaucracy that implements the policy has an important influence on implementation. One of the most basic structural aspects of an organization is its basic work procedures (Standard Operating Procedure, SOP).

\section{ii. People's Business Credit (KUR)}

Understanding of Credit According to the origin of the word "credit" from the word Credere, which in Greek means trust, the point is that if someone gets credit it means they get trust. Whereas for the lender it means giving confidence to someone that the money lent is definitely returned. The definition of "credit" according to Banking Law Number 10 of 1998 is "the provision of money or bills that can be equated with it, based on an agreement or agreement between banks and other parties that requires the borrower to repay the debt after a certain period of time with interest. According to Minister of Finance Regulation Number 10 / PMK.05 / 2009. regarding the People's Business Credit Guarantee Facility, the meaning of KUR is: credit or financing to MSMEs-K (Micro, Small, Medium-Cooperative Enterprises) in the form of providing working capital and investment supported by guarantee facilities for productive businesses. While the definition of People's Business Credit according to Circular Letter of PT. BRI (PERSERO) Tbk Nose: S.08-DIR / ADK / 03/2010, Regarding People's Business Loans: "People's Business Loans are working capital loans and / or investments to Micro, Small, Medium Enterprises and Cooperatives (MSMEs) in the business sector productive and feasible but not yet bankable with a credit limit of up to Rp.500 million (total exposure) and guaranteed by the Guarantee Company".

\section{iii. Definition of Community Empowerment}

The term empowerment is often heard in everyday life in the community and in the academic environment. The term empowerment in Indonesian is a translation of English, namely "empowerment", can be interpreted as "empowerment", in the sense of giving or 
increasing "power" (power) to a weak society. Based on the results of the literature research on the above understanding stated by Ife, (2005) empowerment contains two key notions, namely power and weak groups. Power here means openness only concerns political power in a narrow sense, but political power in a narrow sense, but client power or control over: (a) Personal choices and life opportunities: ability to make decisions regarding lifestyle, place stay, work; (b) Defining needs: ability to determine needs in accordance with their aspirations and desires; (c) Ideas or ideas: the ability to express and contribute ideas in a forum or discussion freely and without pressure; (d) Institutions: the ability to reach, use and influence community institutions, such as social welfare institutions, education, health; (e) Resources: Ability to mobilize formal, informal and community resources; (f) Economic activities: the ability to utilize and manage the mechanisms of production, distribution and exchange of goods and services; (g) Reproduction: ability in relation to birth, child care, education, and socialization. Empowerment shows the ability of people [10] where the state becomes the facilitator in the process [11].

\section{c. Small and Medium Enterprises Warung Tegal (Warteg) and Community Empowerment \\ i. Definition of Small and Medium Enterprises}

According to Law Number 20 of 2008, Small and Medium Enterprises are productive economic businesses that are independent, carried out by individuals or business entities that are not subsidiaries or branches of companies that are owned, controlled or become part of either directly or indirectly with a small business or large business with an amount of net worth or annual sales proceeds as regulated in this Act. the criteria for Small and Medium Enterprises according to the Republic of Indonesia Law Number 20 of 2008, challenging Small and Medium Enterprises are :

Tabel 5. Criteria for Small and Medium Enterprises according to Law No. 20 of

\begin{tabular}{ll}
\hline $\begin{array}{c}\text { Size of } \\
\text { Business }\end{array}$ & \multicolumn{1}{c}{ Criteria } \\
\hline Micro & $\begin{array}{l}\text { Net worth of at most Rp. 50,000,000 excluding land and buildings. } \\
\text { Has annual sales of at most Rp. 300,000,000. }\end{array}$ \\
Small & $\begin{array}{l}\text { Net assets of more than Rp. 50,000,000 up to a maximum of Rp. } \\
500,000,000 \text { excluding land and buildings; or. }\end{array}$ \\
& $\begin{array}{l}\text { Has annual sales of more than Rp. 300,000,000 up to a maximum of } \\
\text { Rp. 2,500,000,000. }\end{array}$ \\
Middle & $\begin{array}{l}\text { Net assets of more than Rp. 500,000,000 up to a maximum of Rp. } \\
\text { class }\end{array}$ \\
& $\begin{array}{l}\text { Has annual sales of more than Rp. 2,500,000,000 up to a maximum } \\
\text { of Rp. 50,000,000,000 }\end{array}$ \\
\hline
\end{tabular}

Source: Law of the Republic of Indonesia Number 2018.

According to the Presidential Decree of the Republic of Indonesia Number 99 of 1998 the definition of Small Business is: Small-scale economic activities of the people with business sectors which in majority are small business activities and need to be protected to prevent unfair business competition. According to the Ministry of Cooperatives and Small and Medium Enterprises (Menegkop and UKM), that what is meant by Small Businesses, including Micro Enterprises, is "Business entities that have a net worth of at most Rp. 200,000,000, excluding land and buildings for business premises, and has annual sales of at most Rp.1,000,000,000. 
Meanwhile, Medium Enterprises are business entities owned by Indonesian citizens who have a net worth greater than Rp. 200,000,000. IDR 10,000,000,000, excluding land and buildings. " Based on Minister of Finance Number Decision 316 / KMK.016 / 1994 dated June 27, 1994, small businesses are defined as individuals or business entities that have carried out activities / businesses that have sales / turnover per year as high as Rp. 600,000,000 or assets / assets as high as -High Rp. 600,000,000 (outside the land and buildings occupied) consists of: (1) badang business (Fa, CV, PT, and cooperatives) and (2) individuals (craftsmen / home industries, farmers, breeders, fishermen, forest encroachers, miners, traders of goods and services). Definition of Small and Medium Enterprises according to Bank Indonesia Circular No. 26/1 / UKK May 29, 1993 are: (a) Small businesses are those that have a maximum total assets of Rp. 600 million, excluding land and houses occupied; (b) Medium-sized businesses are economic enterprises developed by calculating assets (outside land and buildings) ranging from 200 million to less than 600 million with a workforce ranging from 20 people to 99 people.

Meanwhile, according to the Central Bureau of Statistics provides a definition of SMEs based on labor force. "Small businesses are business entities that have a workforce of 5 to 19 people, while medium enterprises are business entities that have a workforce of 20 to 99 people".

Tabel 6. Criteria for Small and Medium Enterprises according to Share Version

\begin{tabular}{|c|c|c|}
\hline Organization & $\begin{array}{c}\text { Type of } \\
\text { Business }\end{array}$ & Description Criteria \\
\hline $\begin{array}{l}\text { Central } \\
\text { Bureau of } \\
\text { Statistics }\end{array}$ & $\begin{array}{l}\text { Micro } \\
\text { Small } \\
\text { Middle class }\end{array}$ & $\begin{array}{l}\text { Less than } 5 \text { workers, including family workers } \\
\text { who were not paid. } \\
\text { Between } 5-19 \\
\text { Between } 20-99\end{array}$ \\
\hline World bank & $\begin{array}{l}\text { Micro } \\
\text { Small } \\
\text { Middle class }\end{array}$ & $\begin{array}{l}\text { Less than } 20 \text { workers. } \\
\text { Between } 20-150 \text { workers. } \\
\text { Assets are less than US } \$ 500 \text { thousand } \\
\text { (excluding land and buildings) }\end{array}$ \\
\hline $\begin{array}{l}\text { Deputy } \\
\text { PKM }\end{array}$ & $\begin{array}{l}\text { Micro } \\
\text { Small }\end{array}$ & Turnover is around US $\$ 25$ thousand- 1 million \\
\hline $\begin{array}{l}\text { Bank } \\
\text { Indonesia }\end{array}$ & Micro & $\begin{array}{l}\text { Assets are less than US } \$ 300 \text { thousand (outside } \\
\text { land and buildings) }\end{array}$ \\
\hline $\begin{array}{l}\text { Depperindag } \\
\text { (Law No. } 9 \\
\text { Th 1999) }\end{array}$ & $\begin{array}{l}\text { Middle class } \\
\text { Small }\end{array}$ & $\begin{array}{l}\text { Assets of more than US } \$ 300 \text { thousand. } \\
\text { Assets are less than US } \$ 100 \text { thousand outside } \\
\text { land and buildings; the turnover of US } \$ 500 \text {, } \\
\text { owned by independent Indonesians, does not } \\
\text { take part in large medium-sized businesses, does } \\
\text { not need a legal entity. }\end{array}$ \\
\hline
\end{tabular}

Source: Rachbini and Arifin, 2017.

The success of a policy is determined or influenced by the policy itself. a policy in its implementation must involve many interests, and the extent to which these interests have an influence on the object of the policy or goal of the policy. While the factors that influence the implementation of policy According to George Edward III, (2002) states: (a) Communication plays an important role in the process of implementing effective policies Communication must be accurate and must be carefully understood by the implementing policies; (b) Resources can be important factors to include adequate staff and good skills to carry out their duties, authority and facilities needed to translate proposals on paper to carry out public services; (c) 
The attitude of policy implementers is the third factor that has important consequences for effective policy implementation. If the implementers are good at a particular policy, and this is support, chances are they are implementing the policy as desired by the initial decision makers.

The following are data that address the realization of the distribution of People's Business Loans to Small and Medium Enterprises at Bank Rakyat Indonesia (BRI) unit of the Sumad Pagang Margadana Sub-District, Tegal City:

Tablel 7. Realization of KUR Distribution to Small and Medium Businesses at BRI

\begin{tabular}{|c|c|c|c|c|c|}
\hline \multirow[b]{3}{*}{ No } & \multicolumn{5}{|c|}{ Bank Pangang Sumur Unit Margadana District, Tegal City } \\
\hline & \multirow{2}{*}{$\begin{array}{l}\text { Business Types of Recipients } \\
\text { of People's Business Loans }\end{array}$} & \multicolumn{3}{|c|}{$\begin{array}{c}\text { Number of Year } \\
\text { Debtors }\end{array}$} & \multirow{2}{*}{$\begin{array}{l}\text { Average } \\
\text { Credit } \\
\text { (IDR } \\
\text { Million/ } \\
\text { Debtor) }\end{array}$} \\
\hline & & 2008 & 2009 & 2010 & \\
\hline 1. & Grocery Store & 136 & 154 & 128 & 10 \\
\hline 2. & Food and Beverage Stalls & 355 & 385 & 490 & 50 \\
\hline 3. & Furniture & 9 & 17 & 20 & 100 \\
\hline 4. & Tailor & 23 & 21 & 24 & 5 \\
\hline 5. & Salon & 26 & 28 & 20 & 6 \\
\hline 5. & Meatball Traders & 26 & 28 & 20 & 7 \\
\hline 6. & Bread and Cakes & 5 & 3 & 1 & 10 \\
\hline 7. & Building Shop & 12 & 20 & 15 & 200 \\
\hline 8. & Electronic store & 14 & 23 & 7 & 100 \\
\hline 9. & Fried traders & 25 & 28 & 15 & 5 \\
\hline 10. & Martabak traders & 27 & 28 & 11 & 5 \\
\hline 11. & Bike shop & 12 & 25 & 17 & 25 \\
\hline
\end{tabular}

Source: People's Business Credit Data, Bank Rakyat Indonesia, Margadana District, Tegal City, 2017.

The data above and based on information from the Department of Industry, Trade and Koprasi, Tegal City Office of Industry, Trade and Cooperatives. It shows that Warung Tegal has a considerable contribution in addition to the other business sectors, which is 10 percent. From the number of traders in Tegal City or approximately 12,000 people as Warung Tegal entrepreneurs on the overseas level, while in the Margadana sub-district the warteg businessman is listed as follows.

\section{Conclusion and Recommendation}

The results of the study mention the implementation of government policy on people's business credit in empowering small and medium enterprises in tegal stalls in Margadana Subdistrict, Tegal City by 45.29 percent. The remaining 54.71 percent are other factors. Other factors that are not optimal, because the implementation of Small and Medium Enterprises does not yet have legal entities. And the location of residence and business is different which causes illegal levies. In this conclusion the researcher can describe the results of the calculation as follows: (1) the independent variable is the implementation of the City Government policy on People's Business Credit in Empowering Warung Tegal Small and 
Medium Enterprises in Margadana District, Tegal City. This is based on the calculated average results obtained from respondents' answers through questionnaires obtained values of 1.77 and included in the category "Enough" (1.67-2.33); (2) the dependent variable is the Empowerment of Warung Tegal Small and Medium Enterprises in Margadana District, Tegal City, which is still not effective. This is based on the results of the average calculation obtained from the respondents' answers through questionnaires obtained values of 1.62 and included in the category "less" (1.00-1.66).

Based on the results of data processing and analysis that have been stated in the discussion chapter, it turns out that the $t$ count is greater than t table. So that obtained $t$ count in the rejection area Ho. Thus Ho's statistical hypothesis which states that there is no influence between the implementation of Government policies concerning People's Business Credit in Empowering Warung Tegal Small and Medium Enterprises in Margadana District, Tegal City is rejected, and the alternative hypothesis $(\mathrm{Ha})$ is accepted. Thus the results of the correlation coefficient between the independent variables on the dependent variable are equal to 0.673 , meaning that the correlation coefficient can be generalized to the population where the sample is taken or the data reflects the state of the population. In calculating the correlation coefficient, i.e. So the coefficient in term is the result shows that there is an implementation of the Tegal City Government policy towards People's Business Credit in Empowering Warung Tegal Small and Medium Enterprises in Margadana District, Tegal City by 45.29 percent. While the remaining 54.71 percent are other factors that also influence the empowerment of Warung Tegal Small and Medium Business entrepreneurs in Margadana District. From the description, the researcher stated that based on the results of the Product Moment Correlation analysis, there was a mutual influence on the implementation of Government policies on People's Business Credit in Empowering Warung Tegal Small and Medium Enterprises in Margadana District, Tegal City. So the hypothesis that the researchers propose is: the implementation of Government policies on People's Business Credit in Empowering Warung Tegal Small and Medium Enterprises in Margadana District, Tegal City, which has been empirically tested through research in the field.

Based on the description in the discussion and conclusions regarding the implementation of the Tegal City Government Policy Against the People's Business Credit in Empowering Warung Tegal Small and Medium Enterprises in Margadana Sub-District, Tegal City, the researcher gave recommendations to the Tegal City Government of Central Java Province, Indonesia, especially in the research location in Margadana District and The Department of Industry, Trade and Koprasi of Tegal City and all of its ranks are as follows: (1) It is expected that the Department of Industry, Trade and Koprasi and other relevant agencies intensify policy dissemination activities related to empowerment, thus encouraging the participation of the community in implementing Government policies on Development Small and Medium Enterprises by taking into account the aspirations, needs and expectations of the community of entrepreneurs and craftsmen; (2) Tegal City Government Especially the Margadana subdistrict government should pay more attention to facilities or facilities and infrastructure that are sufficient to support economic development in SME centers, such as providing information facilities that aim as a medium of communication and policy dissemination in developing and empowering SMEs. Whereas for the Department of Industry, Trade and Cooperatives, it is hoped that more active approach to Warteg UKM centers to provide training and assistance, both technical and moral. 


\section{References}

[1] J. E. Anderson, Marginalization of the Urban Informal Sector, Surabaya. Surabaya: ITS Press, 2006.

[2] Z. Zusmelia, F. Firdaus, and A. Ansofino, "Strengthening Strategies of The Informal Sector in Traditional Market: An Institutional Approach," Acad. Strateg. Manag. J., vol. 18, no. 3, pp. 1-10, 2019.

[3] S. Arikunto, Prosedur Penelitian: Suatu Pendekatan Praktik. Jakarta: Rineka Cipta, 2006.

[4] A. Barnard and J. Specer, Encyclopedia of Social and Cultural Anthropology. Lodon: Routledge, 1997.

[5] Arif Budiman, Teori Pembangunan Dunia Ketiga. Jakarta: Gramedia, 2000.

[6] M. A. Djamaluddin, Use of the Model Development Model in Regional Economic Planning. Jakarta: IIP, 1997.

[7] S. Ermaya, Government Organization and Management in Conditions of Globalization Era. Bandung: Ramadhan, 1996.

[8] A. Gilbert and J. Gugler, Urbanization and Poverty in the Third World. Jakarta: Ghalia Indonesia, 1996.

[9] Sugiyono, Metode Penelitian Kuantitatif, kualitatif dan R \& D. Bandung: Alfabeta, 2016.

[10] E. Suharto, "Human Development and the Urban Informal Sector in Bandung, Indonesia: The Poverty Issue," New Zeal. J. Asian Stud., vol. 4, no. 2, pp. 115-133, 2002.

[11] F. Firdaus, "Evaluasi Proyek Pembangunan Sosial Pada Kelompok Masyarakat Kawasan Hutan Mbeliling, Kab. Manggarai Barat, NTT,” J. Ilmu Sos. Mamangan, vol. 5, no. 1, pp. 13-22, 2016. 